\title{
Fuel moisture sensitivity to temperature and precipitation: climate change implications
}

\author{
M. D. Flannigan ${ }^{1}$ • B. M. Wotton ${ }^{2,3}$ • G. A. Marshall ${ }^{1}$ • \\ W. J. de Groot ${ }^{2}$ - J. Johnston ${ }^{2}$ • N. Jurko ${ }^{2}$ - A. S. Cantin ${ }^{2}$
}

Received: 20 January 2015 / Accepted: 22 September 2015 / Published online: 6 October 2015

(C) The Author(s) 2015. This article is published with open access at Springerlink.com

\begin{abstract}
The objective of this paper is to examine the sensitivity of fuel moisture to changes in temperature and precipitation and explore the implications under a future climate. We use the Canadian Forest Fire Weather Index System components to represent the moisture content of fine surface fuels (Fine Fuel Moisture Code, FFMC), upper forest floor (duff) layers (Duff Moisture Code, DMC) and deep organic soils (Drought Code, DC). We obtained weather data from 12 stations across Canada for the fire season during the 1971-2000 period and with these data we created a set of modified weather streams from the original data by varying the daily temperatures by 0 to $+5{ }^{\circ} \mathrm{C}$ in increments of $1{ }^{\circ} \mathrm{C}$ and the daily precipitation from -40 to $40 \%$ in increments of $10 \%$. The fuel moistures were calculated for all the temperature and precipitation combinations. When temperature increases we find that for every degree of warming, precipitation has to increase by more than $15 \%$ for FFMC, about $10 \%$ for DMC and about $5 \%$ for DC to compensate for the drying caused by warmer temperatures. Also, we find in terms of the number of days equal to or above an FFMC of 91, a critical value for fire spread, that no increase in precipitation amount alone could compensate for a temperature increase of $1{ }^{\circ} \mathrm{C}$. Results from three General Circulation Models (GCMs) and three emission scenarios suggest that this sensitivity to temperature increases will result in a future with drier fuels and a higher frequency of extreme fire weather days.
\end{abstract}

\section{Introduction}

Wildland fire is a frequent occurrence in Canada with 8000 fires burning over 2 million hectares on average every year during the past decade. Most of this area burned results from stand-renewing high-intensity crown fires. These high intensity fires can have significant impact on communities; for example, the fires in Slave Lake in 2011 and Kelowna in 2003 sustained damages measured in

M. D. Flannigan

mike.flannigan@ualberta.ca

1 Department of Renewable Resources, University of Alberta, Edmonton, AB T6G 2H1, Canada

2 Natural Resources Canada, Great Lakes Forestry Centre, Sault Ste Marie, ON P6A 2E5, Canada

3 Faculty of Forestry, University of Toronto, Toronto, ON M5S 3B3, Canada 
$100 \mathrm{~s}$ of millions of dollars (Filmon 2003). Most of the area burned is from a relatively few large fires that occur on a few severe fire weather days (Flannigan and Wotton 2001). Stocks et al. (2003) found that for Canada fires that are 200 ha or larger burn $97 \%$ of the area burned but represent only $3 \%$ of the total number of fires. This skewed distribution is in part due to a highly efficient initial-attack strategy used by fire management agencies in full suppression zones such that most fires are extinguished before they reach 1 ha in size; fires in northern modified or observation zones are often allowed to burn to large sizes when no values at risk are threatened.

Fire activity is strongly influenced by four factors: fuels, climate-weather, ignition agents and people (Flannigan et al. 2005). Fuel amount, type, continuity, structure, and moisture content are critical elements for fire occurrence and spread. In regards to fuel continuity some suggest that at least $30 \%$ of the landscape needs to have fuel for a fire to spread (Hargrove et al. 2000; Finney et al. 2007). This is important in many drier parts of the world where precipitation is required preceding the fire season for the growth of vegetation and the subsequent generation of surface fuels available to carry fire on the landscape (Swetnam and Betancourt 1998; Meyn et al. 2007). This is generally not a concern in Canada where there are sufficient surface fuels for fires to start and spread except where recent fires have consumed the surface fuels. Fuel structure can also be important in fire dynamics; for example, understory trees and shrubs in a forest can act as ladder fuels that help a surface fire to reach the tree crowns and thereby generate a faster moving and much more intense fire. Although the amount of fuel, or fuel load, and fuel distribution (vertical and horizontal) affect fire activity, fuel moisture largely determines whether fuels can sustain ignition and spread (Blackmarr 1972; Wotton et al. 2010), and has been found to be an important factor in the amount of area burned (Flannigan et al. 2005).

There are two common mechanisms for wildfire ignition in Canada: people and lightning. During the past decade, people have started $65 \%$ of the fires and these are responsible for $15 \%$ of the area burned whereas lightning is responsible for the remainder. Lightning-caused fires are responsible for proportionally more area burned because lightning can occur in remote areas so detection and suppression, if any, are delayed as compared to human-caused fires that usually occur in southern full suppression zones. Additionally, lightning fires can occur in large numbers over a short period of time, which can overwhelm a fire management agency's capacity to respond.

Weather and climate - including temperature, precipitation, wind, and atmospheric moisture - are critical aspects of fire activity. Weather is one of the four factors influencing fire activity but it also influences two other factors, fuel and ignitions. Fuel moisture, which may be the most important aspect of fuel flammability, is a function of the weather, and weather and climate also in part determine the type and amount of vegetation (fuel) at any given location. Additionally, lightning is determined by the meteorological conditions. Weather arguably is the best predictor of regional fire activity for time periods of a month or longer. For example, Cary et al. (2006) found that weather and climate best explained modelled area burned estimated from landscape fire models compared with variation in terrain and fuel pattern. Although wind speed may be the primary meteorological factor affecting fire growth of an individual fire, numerous studies suggest that temperature is the most important variable affecting overall annual wildland fire activity, with warmer temperatures leading to increased fire activity (Gillett et al. 2004; Flannigan et al. 2005; Parisien et al. 2011). The reason for the positive relationship between temperature and regional wildland fire is three-fold. First, warmer temperatures will increase evapotranspiration, as the ability for the atmosphere to hold moisture increases rapidly with higher temperatures (Williams et al. 2015), thereby lowering water table position and decreasing forest floor and dead fuel moisture content unless there are significant increases in precipitation. Second, warmer temperatures translate into more 
lightning activity that generally leads to increased ignitions (Price and Rind 1994; Romps et al. 2014). Lastly, warmer temperatures may lead to a lengthening of the fire season with a longer snow period (Wotton and Flannigan 1993; Westerling et al. 2006; Flannigan et al. 2013; Jolly et al. 2015). While testing the sensitivity of landscape fire models to climate change and other factors, Cary et al. (2006) found that area burned increased with higher temperatures. This increase was present even when precipitation increased, although the increase in area burned was greatest for the warmer and drier scenario. The bottom line is that we expect more fire in a warmer world. However, we need to assess the sensitivity of these expected increases in fire activity to changing temperature and precipitation associated with this warmer world.

The global climate is warming and this may have a profound and immediate impact on wildland fire activity. Some suggest that wildland fire activity has already increased due to climate change. For example, Gillett et al. (2004) suggest that the increase in area burned in Canada over the past four decades is due to human-caused increases in temperatures. Dennison et al. (2014) found regional increases in area burned over the western U.S. since 1984. These increases in area burned in Canada and western U.S. were occurring despite stable or increasing fire suppression effectiveness and increased coverage by fire suppression resources. Predicting the impacts of future climate change on fire activity will require an understanding of the impacts and interactions of temperature and precipitation on fuel moisture dynamics, which is a critical factor affecting fire ignition and spread.

The objective of this paper is to examine the sensitivity of fuel moisture as described by the Canadian Fire Weather Index System fuel moisture codes to changes in temperature and precipitation. We do this by determining how much precipitation has to increase for every degree of warming to maintain the same fuel moisture code value. Additionally, we examine the frequency of extremes or frequency of exceeding a threshold in the fuel moisture as fire activity is driven by extreme fire weather (Wang et al. 2015). For example, Podur and Wotton (2011) found that there was almost a $50 \%$ probability of having a day of significant fire growth in the boreal forest region, given that a fire was spreading, occurred when the FFMC was above 92.6Lastly, we interpret the results in terms of future fuel moisture conditions based on temperature and precipitation changes from General Circulation Models (GCMs).

\section{Data \& methods}

We obtained weather data from 12 stations across Canada for the fire season during 19712000. The stations were Kamloops, British Columbia; Fort Smith, North West Territories; Norman Wells, North West Territories; Fort McMurray, Alberta; Grande Prairie, Alberta; Prince Albert, Saskatchewan; The Pas, Manitoba; Sioux Lookout, Ontario; Kapuskasing, Ontario; Bagotville, Quebec; Fredericton, New Brunswick; and Goose, Newfoundland. The variables obtained are those used to calculate components of the Canadian Forest Fire Weather Index (FWI) System (Van Wagner 1987) namely 1200 local standard time (LST) temperature, relative humidity, wind speed (measured at $10 \mathrm{~m}$ above ground in the open) and $24 \mathrm{~h}$ accumulated precipitation (Lawson and Armitage 2008). The FWI System is a weatherbased system that models fuel moisture using a dynamic bookkeeping system, which tracks the drying and wetting of distinct fuel layers in the forest floor. There are three fuel moisture codes that represent the moisture content of fine dead surface fuels (Fine Fuel Moisture Code, FFMC), loosely compacted organic material on the forest floor (Duff Moisture Code, DMC) and deep, compact organic soil layers (Drought Code, DC). Decreasing moisture content in 
these fuel layers is represented in the FWI System by increasing fuel moisture code values; thus higher code values correspond to higher fire danger conditions. The drying time lags (the time it takes for fuel to move $\sim 63 \%$ of the way toward equilibrium moisture content) for these three fuel layers are 2/3 of a day, 15 and 52 days respectively for the FFMC, DMC and DC under normal conditions (temperature $21.1^{\circ} \mathrm{C}$, relative humidity $45 \%$ ) (Van Wagner 1987). These three fuel moisture codes are also directly linked to three fire behavior indices within the FWI System. The DMC and DC are combined to create a generalized index of the amount of fuel available for consumption (Buildup Index, BUI); the FFMC is combined with wind speed to estimate the potential spread rate of a fire (Initial Spread Index, ISI). The BUI and ISI are combined to create the FWI which is an estimate of the potential intensity of a spreading fire.

The FWI System fuel moisture codes and fire behavior indices were calculated for all years and all stations. The FWI System calculations started at the beginning of the fire season (on the third consecutive snow-free day with a $1200 \mathrm{LST}$ temperature of $12^{\circ} \mathrm{C}$ or higher; Lawson and Armitage 2008). For this study, we present results for June 1 to August 31 as some stations for some years had the fire season start after May 1. Over $80 \%$ of area burned in Canada occurs during this June to August period (Stocks et al. 2003).

To explore the impact on fuel moisture resulting from changes in temperature and precipitation we created a set of modified weather streams from the original data by varying the daily temperatures by 0 to $+5{ }^{\circ} \mathrm{C}$ in increments of $1{ }^{\circ} \mathrm{C}$ and the daily precipitation from -40 to $40 \%$ in increments of $10 \%$ for a total of 54 weather streams (5 temperature and 9 precipitation values). The FWI System components were calculated for all the temperature and precipitation combinations. In addition to examining the means of the FFMC, DMC and DC for the temperature and precipitation modified dataset we also calculated the frequency of exceeding certain fuel moisture thresholds. This reflects the fact that the most problematic fire activity occurs during extremely dry periods, which are relatively infrequent in most parts of Canada. We examined the number of days where FFMC values exceeded 84 and 91 (corresponding to roughly to 17 and $10 \%$ moisture content in pine litter respectively), which represent reasonable thresholds for fire ignition and vigorous fire spread respectively (Wotton 2009). For the DMC we examined frequency of days where the DMC exceeded 20, indicating that the upper layer of the decaying forest floor has dried to a moisture content that could sustain combustion (Van Wagner 1972; Wotton 2009). For the DC we examined the number of days that exceeded a value of 400, another common threshold used operationally to identify potential for deep sustained smouldering and increased wildfire mop-up difficulty.

For the projection of temperature and precipitation for the future we selected three GCMs: 1) the CGCM3.1 T47 (Scinocca et al. 2008) from the Canadian Centre for Climate Modelling and Analysis, 2) the HadCM3 (Gordon et al. 2000) from the Hadley Centre for Climate Prediction in the United Kingdom, and 3) the IPSL-CM4 (Marti et al. 2006) from France. These three models were selected to provide a range of projected warming as indicated by mean monthly surface temperature; the Canadian model illustrated the smallest increase and the Hadley model showed the largest increase in monthly mean temperature. There are four families of emission scenarios (IPCC 2000); A1, A2, B1, and B2. We selected three scenarios for evaluation in this study that cover a reasonable range of possibilities: A1B, A2 and B1.

We downloaded the historical (or baseline) monthly data for air temperature, precipitation rate, U-wind vector and V-wind vector variables for each GCM. For CGCM3.1 and IPSLCM4 models, specific humidity was downloaded and converted to relative humidity; for HadCM3, relative humidity was downloaded directly. We then downloaded monthly data for the 21st century for all three GCMs and all three emission scenarios (A1B, A2 and B1). 
Because the GCM grids were different, we interpolated all GCM data to the same $2.5^{\circ} \times 2.5^{\circ}$ grid using an area weighted interpolation program, XConv/convsh 1.91 (Cole 2009).

We calculated 30-year monthly averages for each variable for the 1971-2000 baselines for all three GCMs. For each emission scenario and GCM, we calculated the decadal monthly means for all the variables and for all decades in the 21st century (2001-2010 to 2091-2100). The GCM 30-year baseline monthly averages for air temperature were subtracted from the future decadal monthly while we used a ratio of future over baseline to estimate the changes in precipitation. To generate future daily weather streams we used the calculated monthly anomalies of temperature and monthly precipitation ratios to modify the 1971-2000 daily weather streams. For example, if the average May temperature was $2{ }^{\circ} \mathrm{C}$ warmer in a future decade than in the GCM 1971-2000 period at a station then all the daily May temperatures in the daily baseline data at that station were increased by $2{ }^{\circ} \mathrm{C}$. For precipitation, the decadal future monthly GCM averages were divided by the 30-year GCM monthly baselines to get a ratio of future precipitation over baseline precipitation. We prepared 9 maps $(3 \mathrm{GCMs} \times 3$ scenarios) for 2041-2050 and 2091-2100 showing the changes in temperature and precipitation. All the calculations were done using R (R development Core Team 2012).

\section{Results}

Figures 1, 2 and 3 show the changes in mean seasonal FFMC, DMC and DC with variation in temperature and precipitation averaged for all stations. FFMC increases (becomes drier) as the temperature increases. Precipitation needs to increase by $15 \%$ for each degree of warming to allow FFMC to remain unchanged. Likewise, DMC increases (becomes drier) with temperature, with approximately a $10 \%$ increase in precipitation required to compensate for every degree of warming. The DC increases with temperature can be offset by about a $5 \%$ increase in precipitation for every degree of warming. The sensitivity of fuel moistures to changes in temperature and precipitation become non-linear with decreased precipitation especially for

Fig. 1 Mean seasonal FFMC across all stations as a function of temperature increase and precipitation change. The dashed reference line indicates the baseline FFMC; i.e., no change in temperature or precipitation. The vertical dashed gray line indicates the precipitation change required to compensate for a $1^{\circ}$ temperature increase

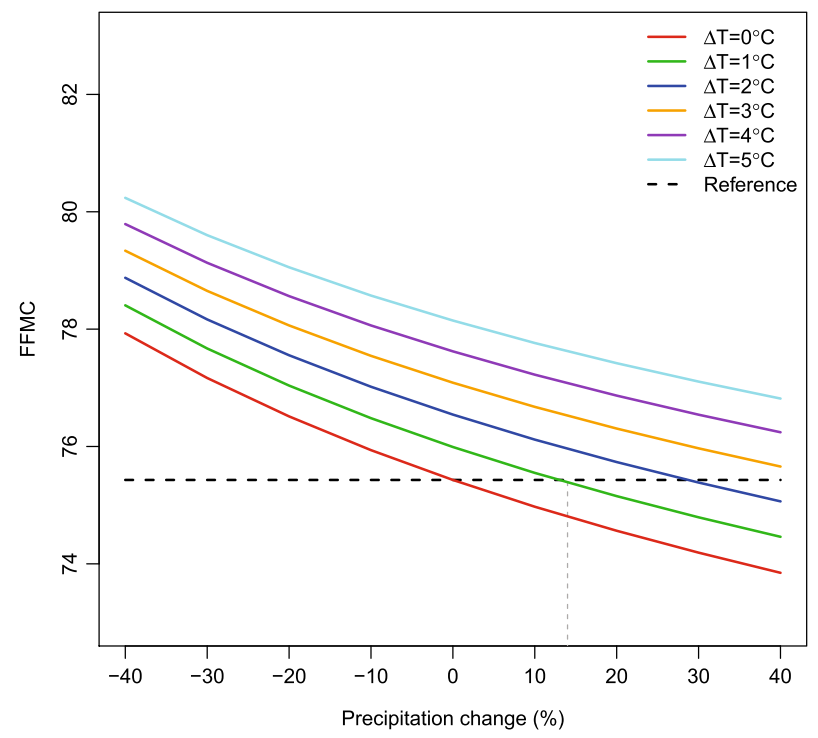


Fig. 2 Mean seasonal DMC across all stations as a function of temperature increase and precipitation change. The dashed reference line indicates the baseline DMC

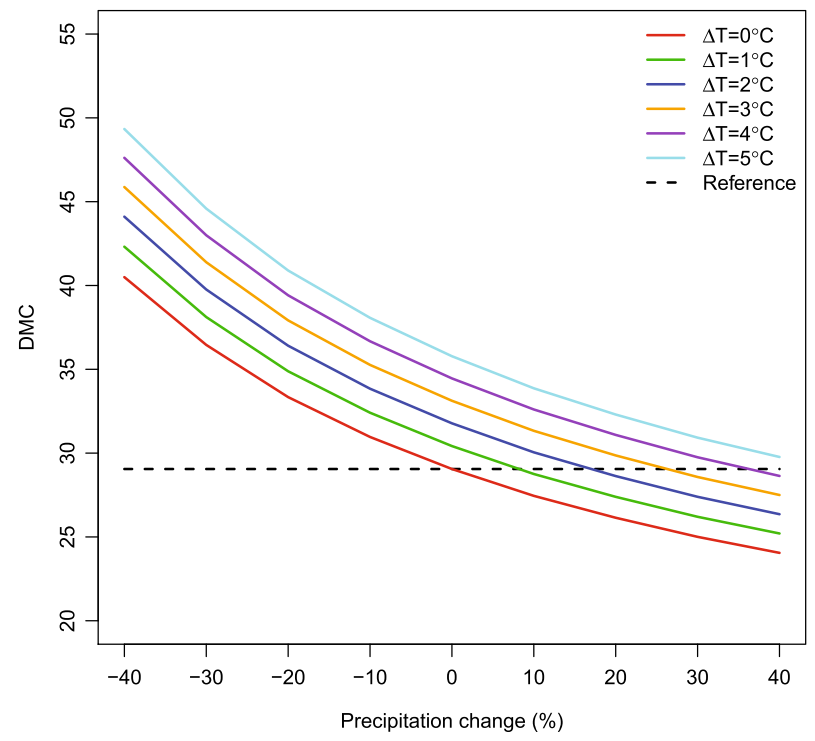

mean seasonal DMC (Fig. 2). As expected, there are significant increases in FFMC, DMC and DC when temperature increases and precipitation decreases (Figs. 1, 2 and 3).

Tables 1, 2, 3 and 4 show frequency of exceedance of key moisture thresholds in fuel layers modeled by the FFMC, DMC and DC. Overall these summarized frequencies show similar results to the change in means of the distributions shown in Figs. 1, 2 and 3, although rainfall increases needed to compensate for rising temperatures tend to be higher. Table 2 (the FFMC $=91$ threshold, indicating strong fire spread potential) shows the relatively muted effect that changes in rainfall have on the number of days hitting this threshold. Not even a $40 \%$ increase in precipitation amount could compensate for an increase in temperature of a degree or more. The slower drying

Fig. 3 Mean seasonal DC across all stations as a function of temperature increase and precipitation change. The dashed reference line indicates the baseline DC

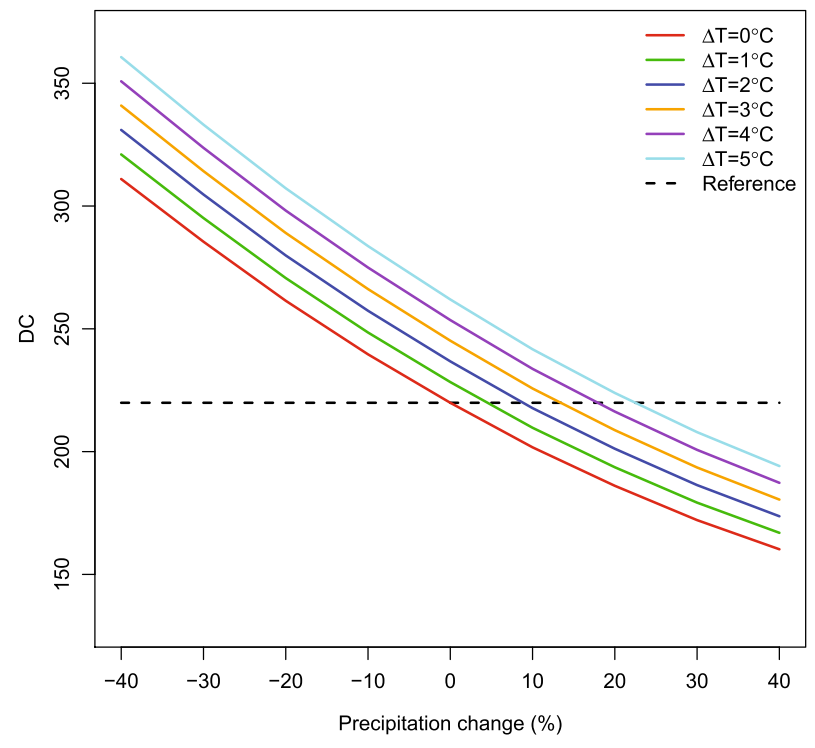


Table 1 Percentage of days when FFMC $\geq 84$ (indicative of ignition sustainability)

\begin{tabular}{|c|c|c|c|c|c|c|c|c|c|c|}
\hline & & \multicolumn{9}{|c|}{ Precipitation change (\%) } \\
\hline & & -40 & -30 & -20 & -10 & 0 & 10 & 20 & 30 & 40 \\
\hline \multirow{6}{*}{$\begin{array}{l}\text { Temperature } \\
\text { increase }\left({ }^{\circ} \mathrm{C}\right)\end{array}$} & 0 & 53.20 & 51.57 & 50.23 & 49.09 & 48.19 & 47.32 & 46.60 & 45.95 & 45.36 \\
\hline & 1 & 54.74 & 53.19 & 51.77 & 50.64 & 49.70 & 48.90 & 48.17 & 47.49 & 46.88 \\
\hline & 2 & 56.15 & 54.66 & 53.42 & 52.27 & 51.31 & 50.46 & 49.64 & 48.99 & 48.40 \\
\hline & 3 & 57.71 & 56.17 & 54.92 & 53.76 & 52.90 & 51.99 & 51.27 & 50.61 & 49.94 \\
\hline & 4 & 59.13 & 57.68 & 56.50 & 55.31 & 54.32 & 53.47 & 52.80 & 52.12 & 51.52 \\
\hline & 5 & 60.60 & 59.05 & 57.81 & 56.89 & 55.89 & 54.99 & 54.22 & 53.65 & 52.99 \\
\hline
\end{tabular}

Grey shading indicates that the frequency was below or equal to the frequency from the reference scenario (i.e., no precipitation or temperature change)

DC, which is a drought indicator featuring a 52 day time lag, tends to require about a $5 \%$ increase in precipitation for each degree increase in air temperature to maintain the same number of days that exceed a DC of 400. Results from individual stations show the same general trends.

Tables 5 and 6 show the temperature and precipitation changes for the fire season for each station by GCM and scenario for 2041-2050 and 2091-2100, respectively. In only the Canadian GCM does the precipitation compensate for the increases in temperature. Figure 4 shows an example of decadal future temperature and precipitation changes relative to the baseline across North America for the IPSL model with the A1B scenario for 2041-2050. There are large regions of Canadian forests that will have significantly drier fuels according to these scenarios although we have much less confidence in the precipitation changes as compared to temperature. There is some variability across models and scenarios but only the Canadian GCM for the A1B and A2 scenarios had just a few stations where precipitation can compensate for the increases in temperature (Tables 5 and 6). There would also be large regions of Canada with significantly higher frequencies of days above the key thresholds like FFMC $\geq 91$ under these scenarios.

\section{Discussion}

Using GCMs and the relationship between temperature, precipitation and fuel moisture, our results indicate that temperature increases will lead to drier fuels in the future. Drier fuels are not only more receptive to ignition but can also sustain more vigorous fire spread. Previous studies of fires in Canada's boreal forest have shown that variations in day-to-day occurrence in human

Table 2 Percentage of days when FFMC $\geq 91$ (indicative of vigorous spread)

\begin{tabular}{|c|c|c|c|c|c|c|c|c|c|c|}
\hline & & \multicolumn{9}{|c|}{ Precipitation change (\%) } \\
\hline & & -40 & -30 & -20 & -10 & 0 & 10 & 20 & 30 & 40 \\
\hline \multirow{6}{*}{$\begin{array}{l}\text { Temperature } \\
\text { increase }\left({ }^{\circ} \mathrm{C}\right)\end{array}$} & 0 & 8.07 & 7.98 & 7.88 & 7.78 & 7.69 & 7.63 & 7.58 & 7.52 & 7.47 \\
\hline & 1 & 9.03 & 8.92 & 8.84 & 8.74 & 8.64 & 8.54 & 8.47 & 8.38 & 8.33 \\
\hline & 2 & 10.12 & 9.96 & 9.88 & 9.79 & 9.69 & 9.55 & 9.48 & 9.42 & 9.32 \\
\hline & 3 & 11.25 & 11.09 & 10.95 & 10.86 & 10.76 & 10.66 & 10.57 & 10.52 & 10.41 \\
\hline & 4 & 12.50 & 12.38 & 12.23 & 12.09 & 11.99 & 11.89 & 11.79 & 11.70 & 11.63 \\
\hline & 5 & 13.88 & 13.69 & 13.57 & 13.46 & 13.32 & 13.22 & 13.10 & 12.98 & 12.91 \\
\hline
\end{tabular}

Grey shading indicates that the frequency was below or equal to the frequency from the reference scenario (i.e., no precipitation or temperature change) 
Table 3 Percentage of days when DMC $\geq 20$ (indicative of sustained combustion potential)

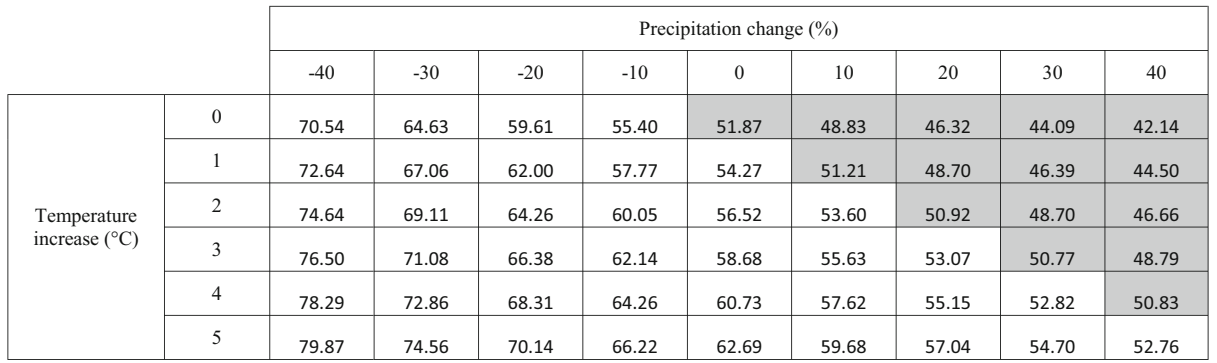

Grey shading indicates that the frequency was below or equal to the frequency from the reference scenario (i.e., no precipitation or temperature change)

caused fires is strongly linked to litter moisture as indicated by the FFMC (Cunningham and Martell 1973; Wotton et al. 2010); similarly day-to-day variation in lightning fire ignition probability is strongly controlled by forest floor organic layer moisture as indicated by the DMC (Wotton and Martell 2005; Wotton et al. 2010). The scenarios evaluated in this current study show that to maintain current average levels of these fuel moisture codes, the increased dryness due to increased temperatures requires significant increases in rainfall amounts. The lower moisture content associated with the higher temperatures tested is likely a conservative estimate of increased drying as we have not included the influence of the decreased relative humidity that would accompany an increase in air temperature during a rain-free period; thus it is likely that in reality to maintain current average fuel moisture levels even greater increases in rainfall would be needed to offset the overall effects atmospheric warming.

Studies using complex parameterizations for fire management agency initial attack systems have shown that the impact of increased fire occurrence can be non-linear; projected increases in fuel dryness can lead to relatively modest increases in overall fire occurrence but these can result in disproportionately large increases in the number of fires escaping initial attack (Wotton et al. 2005; Wotton and Stocks 2006; Podur and Wotton 2010). This disproportionate increase in escaped fires (the fires that ultimately burn the vast amount of area) is driven largely by the increase in lightning fire occurrence. Lightning fires occur in temporal and spatial clusters associated with lightning storms. Increased receptivity of fuels to ignition (i.e., lower fuel moisture content) means increased number of ignitions occurring with each lightning event; thus for a specific fire management region, increased lightning fire occurrence is not spread across the season but is associated with a small number of days. Drier deep

Table 4 Percentage of days when DC $\geq 400$ (indicative of deep sustained smouldering)

\begin{tabular}{|c|c|c|c|c|c|c|c|c|c|c|}
\hline & & \multicolumn{9}{|c|}{ Precipitation change (\%) } \\
\hline & & -40 & -30 & -20 & -10 & 0 & 10 & 20 & 30 & 40 \\
\hline \multirow{6}{*}{$\begin{array}{l}\text { Temperature } \\
\text { increase }\left({ }^{\circ} \mathrm{C}\right)\end{array}$} & 0 & 25.70 & 19.78 & 15.07 & 11.76 & 9.52 & 7.71 & 6.53 & 5.52 & 4.80 \\
\hline & 1 & 28.23 & 21.89 & 16.92 & 13.30 & 10.66 & 8.65 & 7.25 & 6.16 & 5.32 \\
\hline & 2 & 30.69 & 23.94 & 18.77 & 14.86 & 11.87 & 9.70 & 8.04 & 6.88 & 5.91 \\
\hline & 3 & 33.07 & 26.10 & 20.71 & 16.51 & 13.18 & 10.82 & 8.95 & 7.58 & 6.58 \\
\hline & 4 & 35.45 & 28.40 & 22.65 & 18.17 & 14.69 & 11.89 & 9.91 & 8.36 & 7.27 \\
\hline & 5 & 37.82 & 30.62 & 24.58 & 19.91 & 16.17 & 13.08 & 10.95 & 9.21 & 7.96 \\
\hline
\end{tabular}

Grey shading indicates that the frequency was below or equal to the frequency from the reference scenario (i.e., no precipitation or temperature change) 
Table 5 Temperature increase and precipitation changes for the fire season for each station by GCM and scenario for 2041-2050

\begin{tabular}{|c|c|c|c|c|c|c|c|c|c|c|c|c|c|c|c|c|c|c|}
\hline & \multicolumn{6}{|c|}{ Canada-47 } & \multicolumn{6}{|c|}{ France-IPSL } & \multicolumn{6}{|c|}{ Hadley } \\
\hline & \multicolumn{2}{|c|}{ AlB } & \multicolumn{2}{|c|}{$\mathrm{A} 2$} & \multicolumn{2}{|c|}{ B1 } & \multicolumn{2}{|c|}{ AlB } & \multicolumn{2}{|c|}{ A2 } & \multicolumn{2}{|c|}{ B1 } & \multicolumn{2}{|c|}{$\mathrm{A} 1 \mathrm{~B}$} & \multicolumn{2}{|c|}{$\mathrm{A} 2$} & \multicolumn{2}{|c|}{ B1 } \\
\hline & $\begin{array}{l}\Delta \mathrm{T} \\
\left({ }^{\circ} \mathrm{C}\right) \\
\end{array}$ & $\begin{array}{l}\Delta \mathrm{P} \\
(\%) \\
\end{array}$ & $\begin{array}{l}\Delta \mathrm{T} \\
\left({ }^{\circ} \mathrm{C}\right) \\
\end{array}$ & $\begin{array}{l}\Delta \mathrm{P} \\
(\%)\end{array}$ & $\begin{array}{l}\Delta \mathrm{T} \\
\left({ }^{\circ} \mathrm{C}\right) \\
\end{array}$ & $\begin{array}{l}\Delta \mathrm{P} \\
(\%) \\
\end{array}$ & $\begin{array}{l}\Delta \mathrm{T} \\
\left({ }^{\circ} \mathrm{C}\right)\end{array}$ & $\begin{array}{l}\Delta \mathrm{P} \\
(\%)\end{array}$ & $\begin{array}{l}\Delta \mathrm{T} \\
\left({ }^{\circ} \mathrm{C}\right)\end{array}$ & $\begin{array}{l}\Delta \mathrm{P} \\
(\%)\end{array}$ & $\begin{array}{l}\Delta \mathrm{T} \\
\left({ }^{\circ} \mathrm{C}\right) \\
\end{array}$ & $\begin{array}{l}\Delta \mathrm{P} \\
(\%)\end{array}$ & $\begin{array}{l}\Delta \mathrm{T} \\
\left({ }^{\circ} \mathrm{C}\right) \\
\end{array}$ & $\begin{array}{l}\Delta \mathrm{P} \\
(\%) \\
\end{array}$ & $\begin{array}{l}\Delta \mathrm{T} \\
\left({ }^{\circ} \mathrm{C}\right) \\
\end{array}$ & $\begin{array}{l}\Delta \mathrm{P} \\
(\%)\end{array}$ & $\begin{array}{l}\Delta \mathrm{T} \\
\left({ }^{\circ} \mathrm{C}\right)\end{array}$ & $\begin{array}{l}\Delta \mathrm{P} \\
(\%)\end{array}$ \\
\hline Fort Smith, NWT & 0.9 & 13.5 & 1.6 & 3.0 & 1.4 & 20.0 & 3.5 & 13.4 & 2.8 & 40.9 & 2.9 & -1.4 & 1.9 & 25.0 & 1.8 & 19.1 & 2.2 & -6.8 \\
\hline Norman Wells, NWT & 1.9 & 13.1 & 1.9 & 9.2 & 2.1 & 1.4 & 4.0 & -7.5 & 2.9 & 24.6 & 3.1 & 16.1 & 2.0 & 10.8 & 2.0 & 8.4 & 1.6 & 2.8 \\
\hline Fort McMurray, $\mathrm{AB}$ & 0.8 & 10.5 & 1.6 & 5.4 & 1.3 & 15.5 & 3.2 & 13.9 & 2.8 & 34.1 & 2.6 & 7.5 & 2.3 & 13.8 & 1.9 & 17.1 & 2.0 & 3.9 \\
\hline Prince Albert, SASK & 0.6 & 22.8 & 2.0 & 1.3 & 1.5 & -2.9 & 3.5 & 6.2 & 3.2 & 23.7 & 2.4 & 7.1 & 2.6 & -4.8 & 2.1 & 5.9 & 2.0 & -0.5 \\
\hline The Pas, MAN & 0.6 & 22.7 & 2.0 & 1.9 & 1.7 & -2.0 & 3.9 & -5.5 & 3.5 & 19.7 & 2.6 & -3.0 & 2.7 & -5.3 & 2.3 & 7.3 & 2.1 & -7.1 \\
\hline Sioux Lookout, ONT & 1.7 & 13.7 & 1.8 & 1.1 & 1.7 & 1.4 & 3.6 & -10.3 & 3.6 & -13.4 & 1.9 & 7.7 & 2.6 & 19.0 & 2.3 & 8.4 & 1.8 & 11.4 \\
\hline Kapuskasing, ONT & 2.2 & 10.2 & 1.9 & 7.6 & 1.9 & -1.9 & 3.3 & 0.2 & 3.2 & 1.8 & 1.9 & -1.2 & 2.6 & 10.7 & 2.4 & 8.1 & 1.9 & 16.3 \\
\hline Bagotville, QUE & 2.1 & -5.2 & 1.7 & -0.7 & 1.6 & -4.9 & 3.0 & 5.1 & 2.9 & 1.4 & 2.4 & 19.0 & 2.7 & 12.5 & 2.3 & 21.0 & 1.9 & -4.2 \\
\hline Fredericton, NB & 2.1 & -3.4 & 1.7 & -2.7 & 1.5 & -7.5 & 2.9 & 3.3 & 2.6 & -3.0 & 2.1 & 10.8 & 2.7 & 15.5 & 2.3 & 12.8 & 2.3 & -11.1 \\
\hline
\end{tabular}

Shaded areas show where the precipitation will compensate for the increase in temperature in terms of fine fuel moisture

organic layers are also indicative of deeper burning fires (Van Wagner 1972; Stocks 1989) which can therefore lead to release of more greenhouse gases to the atmosphere during flaming and smouldering combustion (Amiro et al. 2009). Deeper burning fires are also more difficult to extinguish often requiring extended periods of mop-up which can tie up suppression resources (Flannigan et al. 2009). As de Groot et al. (2013) observed, fire management, which is already an increasingly challenging exercise (Canadian Council of Forest Ministers 2005), will become even more challenging in the future.

The frequency of days above thresholds for ignition and active fire spread are of great concern in terms of area burned and future fire management. Ultimately the amount of fire on the landscape is driven largely by extremes; a few critical days during which a few critical fires are burning are responsible for much of the area burned (Flannigan and Wotton 2001). Podur and Wotton (2011) found that the $50 \%$ probability of having a day of significant fire growth in the boreal forest region, given that a fire was spreading, occurred when the FFMC was above 92.6. If we see more extremes in the fuel moisture in the future we can expect more days with active fires and more area burned.

There are a number of caveats with this study. We did not change the relative humidity or wind speed and these variables can influence fuel moisture. The influence of wind on drying is relatively minor in the FFMC and is not included in the drying of the sub-surface layers tracked

Table 6 Temperature increase and precipitation changes for the fire season for each station by GCM and scenario for 2091-2100

\begin{tabular}{|c|c|c|c|c|c|c|c|c|c|c|c|c|c|c|c|c|c|c|}
\hline & \multicolumn{6}{|c|}{ Canada- 47} & \multicolumn{6}{|c|}{ France-IPSL } & \multicolumn{6}{|c|}{ Hadley } \\
\hline & \multicolumn{2}{|c|}{ AlB } & \multicolumn{2}{|c|}{$\mathrm{A} 2$} & \multicolumn{2}{|c|}{ B1 } & \multicolumn{2}{|c|}{ AlB } & \multicolumn{2}{|c|}{ A2 } & \multicolumn{2}{|c|}{$\mathrm{B} 1$} & \multicolumn{2}{|c|}{ AlB } & \multicolumn{2}{|c|}{ A2 } & \multicolumn{2}{|c|}{ B1 } \\
\hline & $\begin{array}{l}\Delta \mathrm{T} \\
\left({ }^{\circ} \mathrm{C}\right)\end{array}$ & $\begin{array}{l}\Delta \mathrm{P} \\
(\%)\end{array}$ & $\begin{array}{l}\Delta \mathrm{T} \\
\left({ }^{\circ} \mathrm{C}\right)\end{array}$ & $\begin{array}{l}\Delta \mathrm{P} \\
(\%)\end{array}$ & $\begin{array}{l}\Delta \mathrm{T} \\
\left({ }^{\circ} \mathrm{C}\right) \\
\end{array}$ & $\begin{array}{l}\Delta \mathrm{P} \\
(\%)\end{array}$ & $\begin{array}{l}\Delta \mathrm{T} \\
\left({ }^{\circ} \mathrm{C}\right) \\
\end{array}$ & $\begin{array}{l}\Delta \mathrm{P} \\
(\%)\end{array}$ & $\begin{array}{l}\Delta \mathrm{T} \\
\left({ }^{\circ} \mathrm{C}\right)\end{array}$ & $\begin{array}{l}\Delta \mathrm{P} \\
(\%)\end{array}$ & $\begin{array}{l}\Delta \mathrm{T} \\
\left({ }^{\circ} \mathrm{C}\right)\end{array}$ & $\begin{array}{l}\Delta \mathrm{P} \\
(\%)\end{array}$ & $\begin{array}{l}\Delta \mathrm{T} \\
\left({ }^{\circ} \mathrm{C}\right) \\
\end{array}$ & $\begin{array}{l}\Delta \mathrm{P} \\
(\%)\end{array}$ & $\begin{array}{l}\Delta \mathrm{T} \\
\left({ }^{\circ} \mathrm{C}\right)\end{array}$ & $\begin{array}{l}\Delta \mathrm{P} \\
(\%)\end{array}$ & $\begin{array}{l}\Delta \mathrm{T} \\
\left({ }^{\circ} \mathrm{C}\right)\end{array}$ & $\begin{array}{l}\Delta \mathrm{P} \\
(\%)\end{array}$ \\
\hline Fort Smith, NWT & 2.4 & 32.1 & 3.9 & 24.4 & 0.6 & 6.7 & 5.8 & -19.7 & 7.1 & 10.0 & 4.4 & 23.3 & 6.2 & -0.2 & 5.3 & 17.7 & 3.4 & 3.1 \\
\hline Norman Wells, NWT & 2.8 & 39.8 & 3.9 & 29.7 & 1.4 & 12.1 & 6.0 & -12.5 & 7.0 & 0.1 & 4.1 & 15.0 & 4.5 & 20.9 & 5.1 & 15.6 & 3.0 & 9.3 \\
\hline Fort McMurray, $\mathrm{AB}$ & 2.7 & 7.9 & 3.9 & 16.9 & 0.6 & 16.0 & 5.3 & 13.9 & 6.6 & 1.8 & 4.0 & 7.2 & 5.9 & -4.3 & 5.4 & 7.7 & 3.1 & 7.3 \\
\hline Prince Albert, SASK & 3.1 & 6.4 & 4.3 & 4.5 & 0.9 & 19.7 & 5.6 & 10.5 & 6.6 & -2.1 & 4.2 & 15.3 & 6.3 & -9.6 & 6.2 & -8.0 & 3.2 & 2.4 \\
\hline The Pas, MAN & 3.2 & 12.3 & 4.4 & 1.7 & 0.8 & 16.9 & 6.0 & 4.0 & 7.3 & -13.7 & 4.6 & 12.8 & 6.4 & -4.8 & 6.4 & -2.3 & 3.4 & 3.2 \\
\hline Sioux Lookout, ONT & 3.7 & -3.2 & 5.0 & -5.8 & 1.9 & -5.2 & 6.1 & -9.7 & 6.7 & -5.7 & 4.7 & -11.1 & 5.8 & 1.4 & 6.5 & 1.5 & 3.3 & 19.6 \\
\hline Kapuskasing, ONT & 3.8 & -0.9 & 4.8 & -6.0 & 1.9 & 1.0 & 5.9 & -1.2 & 6.5 & -6.0 & 4.6 & -10.7 & 5.8 & -3.0 & 6.7 & 2.6 & 3.5 & 4.0 \\
\hline Bagotville, QUE & 3.6 & -2.7 & 4.5 & -13.0 & 1.6 & -4.1 & 5.2 & -7.0 & 6.1 & 10.4 & 3.9 & 10.3 & 5.5 & 2.2 & 6.6 & 4.1 & 3.7 & 20.8 \\
\hline Fredericton, NB & 3.5 & -2.5 & 4.7 & -21.0 & 1.5 & 3.1 & 4.6 & -13.0 & 5.7 & 4.2 & 3.3 & 3.4 & 5.3 & 9.1 & 6.6 & -2.8 & 4.0 & 16.0 \\
\hline
\end{tabular}

Shaded areas show where the precipitation will compensate for the increase in temperature in terms of fine fuel moisture 


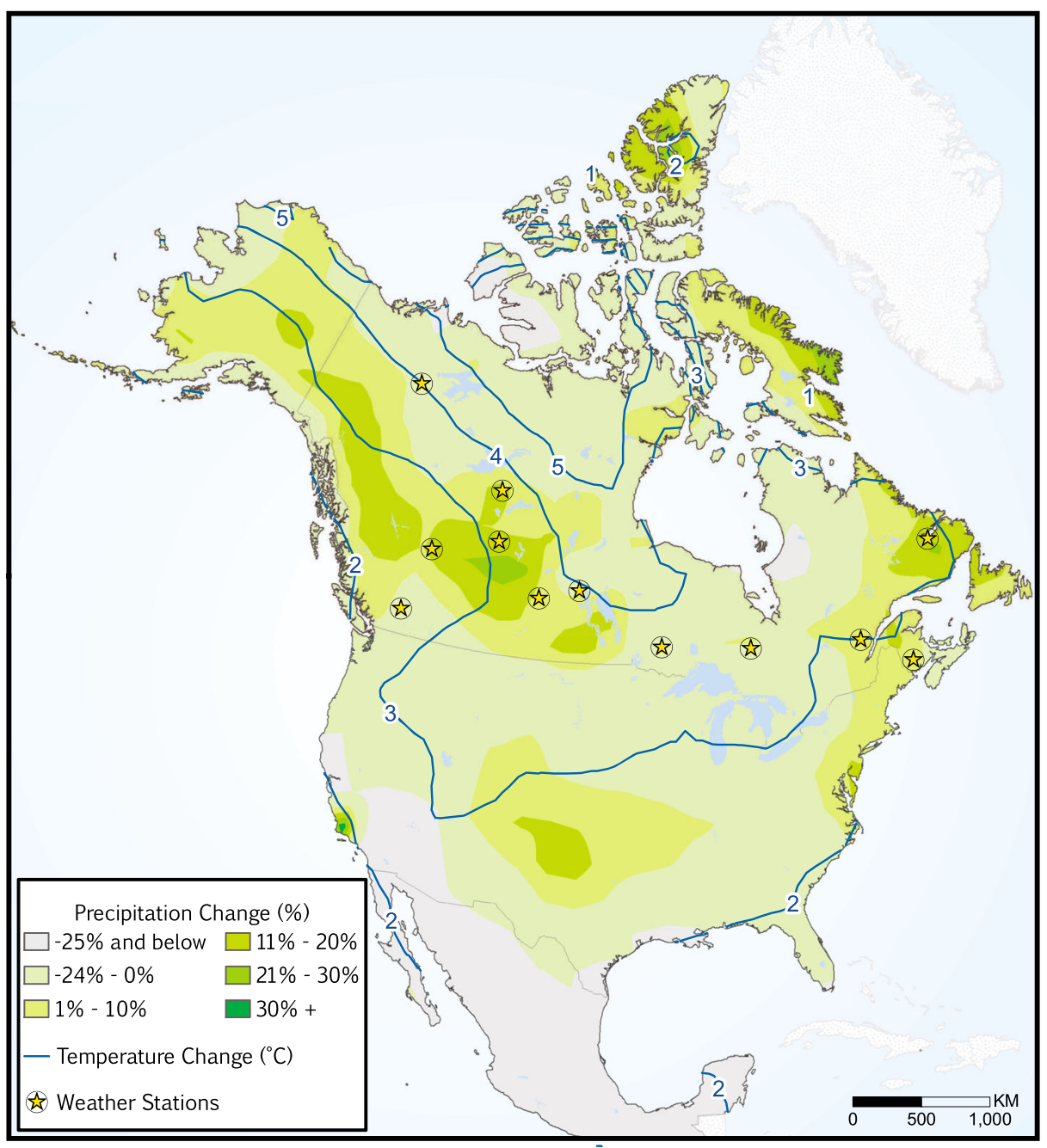

Fig. 4 Decadal future temperature increase and precipitation changes relative to the baseline from the IPSL model under the A1B emissions scenario for 2041-2050

by the DMC. As temperature goes up typically relative humidity goes down and this decreased humidity would further increase the drying rate and decrease equilibrium moisture levels, and thus lead to an overall increase in fuel drying. Indeed sensitivity studies on weather inputs and outputs of the FWI System have shown there to be strong influence of relative humidity (Dowdy et al. 2010). We chose not to modify relative humidity in our temperature scenarios to provide a simpler albeit more conservative presentation of the amount of drying that might occur with increased temperatures. A number of other studies have included modified relative humidity and wind speed according to GCM projections of future fire climate. The results of these studies are quite consistent with our observations of an overall decrease in fuel moisture and consequent increase in the probability of ignition and spread (Flannigan and Harrington 1988; Wotton et al. 2010). Precipitation frequency is unchanged so this study addresses sensitivity of precipitation amounts but not the sensitivity to precipitation frequency. If the frequency of precipitation 
changes in the future this might have significant influences on fire activity (Flannigan and Harrington 1988). Evaluation of potential future climates using daily outputs from GCMs has indeed shown increased overall dryness of forest fuel layers as indicated by FWI System moisture codes (Wotton et al. 2010). Also, we have assumed that vegetation/fuel amount and type remains static and we know that this is unlikely (Jiang et al. 2013). Future work should use a dynamic vegetation model. Finally, we believe that our results may be on the conservative side as there are indications that there will be more extremes with long periods without precipitation in the future due to changes in the upper atmospheric circulation patterns (Petoukhov et al. 2013).

This study has shown the relationship between temperature and precipitation and the result on fuel moisture as determined by the FWI System. Temperature increases in the future will most likely lead to more fire activity due to drier fuels alone. Changes in relative humidity, winds, fuels (type, horizontal and vertical distribution etc.), ignitions and fire season length will also influence fire activity in the future. The bottom line is that a warmer world will have more fire.

Open Access This article is distributed under the terms of the Creative Commons Attribution 4.0 International License (http://creativecommons.org/licenses/by/4.0/), which permits unrestricted use, distribution, and reproduction in any medium, provided you give appropriate credit to the original author(s) and the source, provide a link to the Creative Commons license, and indicate if changes were made.

\section{References}

Amiro BD, Cantin A, Flannigan MD, de Groot WJ (2009) Future emissions from Canadian boreal forest fires. Can J For Res 39:383-395

Blackmarr WH (1972) Moisture content influences ignitability of slash pine litter. USDA Forest Service Research Note SE-173. U.S. Department of Agriculture

Canadian Council of Forest Ministers (2005) Canadian Wildland Fire Strategy: a vision for an innovative and integrated approach to managing the risks. Canadian Forest Service, Edmonton, Alberta. Catalogue No. Fo134-1/2005E, ISBN 0-662-42194-9. 18p

Cary GJ, Keane RE, Gardner RH, Lavorel S, Flannigan MD, Davies ID, Li C, Lenihan JM, Rupp TS, Mouillot F (2006) Comparison of the sensitivity of landscape-fire-succession models to variation in terrain, fuel pattern, climate and weather. Landsc Ecol 21:121-137

Cole J (2009) Xconv/Convsh (Version 1.91). Software http://badc.nerc.ac.uk/help/software/xconv/

Cunningham AA, Martell DL (1973) A stochastic model for the occurrence of man-caused forest fires. Can J For Res 3:282-287

de Groot WJ, Flannigan MD, Cantin AS (2013) Climate change impacts of future boreal fire regimes. For Ecol Manag 294:35-44

Dennison PE, Brewer SC, Arnold JD, Mortiz MA (2014) Large wildfire trends in the western United States, 1984-2011. Geophys Res Lett 41:2928-2933

Dowdy AJ, Mills GA, Finkele K, de Groot W (2010) Index sensitivity analysis applied to the Canadian Forest Fire Weather Index and the McArthur Forest Fire Danger. Meteorol Appl 17:298-312

Filmon G (2003) Firestorm 2003 Provincial Review. British Columbia. 100 pp

Finney MA, Seli RC, McHugh CW, Ager AA, Bahro B, Agee JK (2007) Simulation of long-term landscapelevel fuel treatment effects on large wildfires. Int J Wildland Fire 16:712-727

Flannigan MD, Harrington JB (1988) A study of the relation of meteorological variables to monthly provincial area burned by wildfire in Canada 1953-80. J Appl Meteorol 27:441-452

Flannigan MD, Wotton BM (2001) Climate, weather, and area burned. In: Johnson EA, Miyanishi K (eds) Forest fires behavior and ecological effects. Academic, New York, pp 351-373

Flannigan MD, Logan KA, Amiro BD, Skinner WR, Stocks BJ (2005) Future area burned in Canada. Clim Chang 72:1-16

Flannigan MD, Stocks BJ, Turetsky MR, Wotton BM (2009) Impact of climate change on fire activity and fire management in the circumboreal forest. Glob Chang Biol 15:549-560. doi:10.1111/j.1365-2486.2008.01660.x

Flannigan MD, Cantin AS, de Groot WJ, Wotton M, Newbery A, Gowman LM (2013) Global wildland fire season severity in the 21st century. For Ecol Manag 294:54-61 
Gillett NP, Weaver AJ, Zwiers FW, Flannigan MD (2004) Detecting the effect of climate change on Canadian forest fires. Geophys Res Lett 31, L18211. doi:10.1029/2004GL020876

Gordon C, Cooper C, Senior CA, Banks H, Gregory JM, Johns TC, Mitchell JFB, Wood RA (2000) The simulation of SST, sea ice extents and ocean heat transports in a version of the Hadley Centre coupled model without flux adjustments. Clim Dyn 16:147-168

Hargrove WW, Gardner RH, Turner MG, Romme WH, Despain DG (2000) Simulating fire patterns in heterogeneous landscapes. Ecol Model 135:243-263

IPCC (2000) Emissions Scenarios. Cambridge University Press, Cambridge

Jiang X, Rauscher SA, Ringler TD, Lawrence DM, Williams AP, Allen CD, Stiener AL, Cai DM, McDowell NG (2013) Projected future changes in vegetation in western North America in the twenty-first century. J Clim 26:3671-3687

Jolly WM, Cochrane MA, Freeborn PH, Holden ZA, Brown TJ, Williamson GJ, Bowman DM (2015) Climateinduced variations in global wildfire danger from 1979 to 2013. Nat Commun 6. doi:10.1038/ncomms8537

Lawson BD, Armitage OB (2008) Weather guide for the Canadian Forest Fire Danger Rating System. Natural Resources Canada, Canadian Forest Services, Northern Forestry Centre, Edmonton, AB

Marti O, Braconnot P, Bellier J, Benshila R, Bony S, Brockmann P, Cadule P, Caubel A, Denvil S, Dufresne J-L, Fairhead L, Filiberti M-A, Foujols M-A, Fichefet T, Friedlingstein P, Gosse H, Grandpeix J-Y, Hourdin F, Krinner G, Lévy C, Madec G, Musat I, de Noblet N, Polcher J, Talandier C (2006) The new IPSL climate system model: IPSL-CM4. Institut Pierre Simon Laplace des Sciences de l'Environnement Global, Paris

Meyn A, White PS, Buhk C, Jentsch A (2007) Environmental drivers of large, infrequent wildfires: the emerging conceptual model. Prog Phys Geogr 31:287-312

Parisien M-A, Parks SA, Krawchuk MA, Flannigan MD, Bowman LM, Moritz MA (2011) Scale-dependent controls on the area burned in the boreal forest of Canada, 1980-2005. Ecol Appl 21:789-805

Petoukhov V, Rahmstorf S, Petri S, Schellnhuber HJ (2013) Quasiresonant amplification of planetary waves and recent northern hemisphere weather extremes. Proc Natl Acad Sci 110:5336-5341

Podur J, Wotton BM (2010) Will climate change overwhelm fire management capacity? Ecol Model 221:1301-1309

Podur J, Wotton BM (2011) Defining fire spread event days for fire growth modeling. Int J Wildland Fire 20:497-507

Price C, Rind D (1994) Possible implications of global climate change on global lightning distributions and frequencies. J Geophys Res 99(D5):10823-10831. doi:10.1029/94JD00019

R Development Core Team (2012) R: A language and environment for statistical computing. R Foundation for Statistical Computing. Vienna, Austria

Romps DM, Seeley JT, Vollaro D, Molinari J (2014) Projected increase in lightning strikes in the United States due to global warming. Science 346:851-854

Scinocca JF, McFarlane NA, Lazare M, Li J, Plummer D (2008) Technical note: the CCCma third generation AGCM and its extension into the middle atmosphere. Atmos Chem Phys 8:7055-7074

Stocks BJ (1989) Fire behavior in mature jack pine. Can J For Res 19:783-790

Stocks BJ, Mason JA, Todd JB, Bosch EM, Wotton BM, Amiro BD, Flannigan MD, Hirsch KG, Logan KA, Martell DL, Skinner WR (2003) Large forest fires in Canada, 1959-1997. J Geophys Res 108:8149. doi:10. 1029/2001JD000484

Swetnam TW, Betancourt JL (1998) Mesoscale disturbance and ecological response to decadal climatic variability in the American Southwest. J Clim 11:3128-3147

Van Wagner CE (1972) Duff consumption by fire in eastern pine stands. Can J For Res 2:34-39

Van Wagner CE (1987) Development and structure of the Canadian Forest Fire Weather Index System. Forestry Technical Report 35. Canadian Forestry Service, Ottawa, ON

Wang X, Thompson DK, Marshall GA, Tymstra C, Carr R, Flannigan MD (2015) Increasing frequency of extreme fire weather in Canada with climate change. Clim Chang. doi:10.1007/s10584-015-1375-5

Westerling AL, Hidalgo HG, Cayan DR, Swetnam TW (2006) Warming and earlier spring increase in Western U.S. forest wildfire activity. Science 313:940-943

Williams AP, Seager R, Macalady AK, Berkelhammer M, Crimmins MA, Swetnam TW, Trugman AT, Buenning N, Noone D, McDowell NG, Hryniw N, Mora CI, Rahn T (2015) Correlations between components of the water balance and burned area reveal new insights for predicting forest fire area in the southwest United States. Int J Wildland Fire 24:14-26

Wotton BM (2009) Interpreting and using outputs from the Canadian Forest Fire Danger Rating System in research applications. Environ Ecol Stat 16:107-131

Wotton BM, Flannigan MD (1993) Length of the fire season in a changing climate. For Chron 69:187-192

Wotton BM, Martell DL (2005) A lightning fire occurrence model for Ontario. Can J For Res 35:1389-1401

Wotton BM, Stocks BJ (2006) Fire management in Canada: vulnerability and risk trends. In: Hirsch KG, Fuglem P (eds) Canadian Wildland Fire Strategy: Background synthesis, analysis, and perspectives. Canadian Council of Forest Ministers. Natural Resources Canada, Canadian Forest Service, Northern Forestry Centre, Edmonton, Alberta. pp 49-55 
Wotton, BM, Logan KA, McAlpine RS (2005) Climate change and the future fire environment in Ontario: fire occurrence and fire management impacts. Climate Change Research Report CCRR-01. Ontario Ministry of Natural Resources

Wotton BM, Nock CA, Flannigan MD (2010) Forest fire occurrence and climate change in Canada. Int J Wildland Fire 19:253-271 